\title{
Effects of D-Amino Acid Oxidase Inhibitor on the Extracellular D-Alanine Levels and the Efficacy of D-Alanine on Dizocilpine-Induced Prepulse Inhibition Deficits in Mice
}

\author{
Mao Horio ${ }^{1}$, Yuko Fujita ${ }^{1}$, Tamaki Ishima ${ }^{1}$, Masaomi Iyo ${ }^{2}$, Dana Ferraris ${ }^{3}$, Takashi Tsukamoto $^{3}$ and \\ Kenji Hashimoto, ${ }^{1, *}$
}

\author{
${ }^{I}$ Division of Clinical Neuroscience, Chiba University Center for Forensic Mental Health, Chiba 260-8670, Japan; \\ ${ }^{2}$ Department of Psychiatry, Chiba University Graduate School of Medicine, Chiba 260-8670, Japan and ${ }^{3}$ Eisai Research \\ Institute, Baltimore, MD 21224, USA
}

\begin{abstract}
D-Alanine, one of D-amino acids present in the mammalian brain, is a selective and potent agonist at the Nmethyl-D-aspartate (NMDA) receptors. Like D-serine, D-alanine is reported to be effective in the treatment of schizophrenia. However, orally given D-alanine is metabolized substantially by D-amino acid oxidase (DAAO), diminishing its oral bioavailability. In this study, we studied the effects of oral D-alanine administration with or without the novel DAAO inhibitor, 5-chloro-benzo[d]isoxazol-3-ol (CBIO), on the extracellular D-alanine levels in the brain and on the prepulse inhibition (PPI) deficits after administration of the NMDA receptor antagonist dizocilpine. Co-administration of CBIO (30 $\mathrm{mg} / \mathrm{kg}$ ) with D-alanine $(100 \mathrm{mg} / \mathrm{kg})$, but not D-alanine $(100 \mathrm{mg} / \mathrm{kg})$ alone, significantly attenuated dizocilpine $(0.1$ $\mathrm{mg} / \mathrm{kg}$ )-induced PPI deficits in mice. The in vivo microdialysis study of the conscious and free moving mice revealed that co-administration of CBIO $(30 \mathrm{mg} / \mathrm{kg})$ significantly increased extracellular levels of D-alanine in the frontal cortex after oral administration of D-alanine $(100 \mathrm{mg} / \mathrm{kg})$. These findings suggest that co-administration of CBIO can increase the bioavailability of D-alanine after oral administration of D-alanine, and that co-administration of CBIO can enhance the efficacy of D-alanine on dizocilpine-induced PPI deficits. Therefore, combination of D-alanine and a DAAO inhibitor such as CBIO offers new therapeutic potential for treatment of schizophrenia.
\end{abstract}

Key Words: D-Alanine, D-amino acid oxidase, NMDA receptors, Prepulse inhibition, Schizophrenia, Bioavailability.

\section{INTRODUCTION}

Several lines of evidence suggest that a dysfunction in the glutamatergic neurotransmission via the N-methyl-Daspartate (NMDA) receptors might be involved in the pathophysiology of schizophrenia [1-9]. Based on the hypofunction hypothesis of NMDA receptors in schizophrenia, the drugs which can stimulate the function of NMDA receptors would be attractive drugs for novel treatment of schizophrenia [10-15].

D-Alanine is the first D-amino acid found in serum of guinea pig and mice [16]. Subsequent studies demonstrated that free D-alanine is one of the D-amino acids naturally occurring in the mammalian tissues including brain and blood [17-22]. D-Alanine, like D-serine, is also a selective and potent agonist at the glycine-modulatory site on the NMDA receptors [23-25]. Accumulating evidence suggests that, similar to D-serine, D-alanine also might be involved in the pathophysiology of schizophrenia. First, bilateral injection of D-alanine, but not L-alanine, into the lateral ventricle significantly blocked hyperlocomotion in rats after administration of the NMDA receptor antagonist phencyclidine (PCP) [26]. Second, in a 6-week double-blind, placebo-

\footnotetext{
*Address correspondence to this author at the Division of Clinical Neuroscience, Chiba University Center for Forensic Mental Health, 1-8-1 Inohana, Chiba 260-8670, Japan; Tel: +81-43-226-2147; Fax: +81-43-226-2150; Email: hashimoto@faculty.chiba-u.jp
}

controlled study, Tsai et al. [27] reported that D-alanine (100 $\mathrm{mg} / \mathrm{kg} /$ day) significantly improved schizophrenic symptoms when used as adjunctive to conventional antipsychotic drugs. Third, mRNA expression and activity of D-amino acid oxidase (DAAO), which can metabolize D-alanine, is increased in the postmortem brain of schizophrenic patients [28, 29]. Fourth, the G72 gene on the chromosome $13 \mathrm{q}$ was significantly associated with schizophrenia [30]. The G72 gene is given the designation DAAO activator since G72 protein was shown to interact with physically with DAAO [30]. A recent meta-analysis shows highly significant evidence of association between nucleotide variations in the G72/G30 region and schizophrenia [31]. Taken all together, it is likely that alterations in brain D-alanine levels may be implicated in the pathophysiology of schizophrenia.

In animals, D-alanine, like D-serine, is suggested to be metabolized substantially by DAAO in peripheral organs, diminishing its oral bioavailability $[32,33]$. These findings prompted us to identify small molecule DAAO inhibitors that can be co-administered with D-amino acids (e.g., Dserine and D-alanine) to minimize its metabolism by DAAO. Recently, we reported that oral administration of the novel and potent DAAO inhibitor, 5-chloro-benzo[d]isoxazol-3-ol (CBIO) (Fig. 1), in conjunction with D-serine could enhance the plasma and brain levels of D-serine in rats and mice compared to the oral administration of D-serine alone [34, $35]$.

2009 Bentham Open 


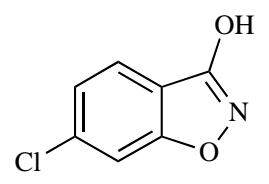

$\mathrm{CBIO}\left(\mathrm{IC}_{50}=188 \mathrm{nM}\right)$

Fig. (1). Chemical structure of CBIO.

The $\mathrm{IC}_{50}$ value of CBIO for DAAO was $188 \mathrm{nM}$ [34].

The prepulse inhibition (PPI) deficits have been widely used as an animal model of schizophrenia [36, 37]. In the present study, we examined the effects of oral D-alanine administration with or without CBIO on the PPI deficits in mice after administration of the NMDA receptor antagonist dizocilpine. Furthermore, using the in vivo microdialysis method, we measured the extracellular levels of D-alanine in the frontal cortex after oral administration of D-alanine with or without CBIO.

\section{METHODS}

\section{Animals}

Male Slc:ddy mice (6 weeks old) weighing 25-30 g were purchased from SLC Japan (Hamamatsu, Shizuoka, Japan). The mice were housed in clear polycarbonate cages $(22.5 \times 33.8 \times 14.0 \mathrm{~cm})$ and in groups of 5 or 6 mice under a controlled 12/12-h light-dark cycle (light from 7:00 AM to 7:00 PM), with room temperature at $23 \pm 1^{\circ} \mathrm{C}$ and humidity at $55 \pm 5 \%$. The mice were given free access to water and food pellets. The experimental procedure was approved by the Animal Care and Use Committee of Chiba University.

\section{Drugs and Drug Administration}

(+)-MK-801 hydrogen maleate (dizocilpine) $(0.1 \mathrm{mg} / \mathrm{kg}$ as a hydrogen maleate salt, Sigma-Aldrich Corporation., St. Louis, MO, USA), dissolved in physiological saline, was injected subcutaneously (s.c.) in a volume of $10 \mathrm{ml} / \mathrm{kg}$. The dose $(0.1 \mathrm{mg} / \mathrm{kg})$ of dizocilpine was selected because this dose caused PPI deficits in mice as reported previously [35, 38]. D-Alanine $(100,300$ or $1000 \mathrm{mg} / \mathrm{kg}$, Wako Pure Chemical Industries, Ltd., Tokyo, Japan), dissolved in $0.5 \%$ carbomethoxycellulose (CMC: Wako Pure Chemical Co., Tokyo, Japan), was administered orally in a volume of 10 $\mathrm{ml} / \mathrm{kg}$. CBIO $(30 \mathrm{mg} / \mathrm{kg}$ ) $[34,35]$ was suspended in $0.5 \%$ $\mathrm{CMC}$, was administered orally in a volume of $10 \mathrm{ml} / \mathrm{kg}$. The other chemicals used were purchased from commercial sources.

\section{Measurement of Acoustic Startle Reactivity and Prepulse Inhibition of Startle}

The mice were tested for their acoustic startle reactivity (ASR) in a startle chamber (SR-LAB, San Diego Instruments, CA, USA) using standard methods described by Swerdlow and Geyer [37]. After an initial 10-min acclimation period in the chamber, the test sessions began. They consisted of six trial types: (1) pulse alone, $40 \mathrm{~ms}$ broadband burst; pulse preceded $100 \mathrm{~ms}$ by a $20 \mathrm{~ms}$ prepulse that was (2) $4 \mathrm{~dB}$, (3) $8 \mathrm{~dB}$, (4) $12 \mathrm{~dB}$, or (5) $16 \mathrm{~dB}$ over background (65 dB); and (6) background only (no stimulus). The amount of prepulse inhibition (PPI) is expressed as the percentage decrease in the amplitude of the startle reactivity caused by presentation of the prepulse (\% PPI).

D-Alanine $(100,300$ or $1000 \mathrm{mg} / \mathrm{kg})$ with or without CBIO $(30 \mathrm{mg} / \mathrm{kg})[34,35]$, or vehicle $(0.5 \% \mathrm{CMC})(10$ $\mathrm{ml} / \mathrm{kg}$ ) were administered $60 \mathrm{~min}$ (including 10-min acclimation period) before the machine records, and dizocilpine $(0.1$ $\mathrm{mg} / \mathrm{kg})$ or saline $(10 \mathrm{ml} / \mathrm{kg})$ was administered s.c. $10 \mathrm{~min}$ (including 10-min acclimation period) before. The PPI test lasted $20 \mathrm{~min}$ in total.

\section{In Vivo Microdialysis Study in Free-Moving Mice}

Mice were anesthetized with sodium pentobarbital prior to the stereotaxic implantation of a probe into the left frontal cortex $(+2.1 \mathrm{~mm}$ anteroposterior, $+1.0 \mathrm{~mm}$ mediolateral from the bregma, and $-1.2 \mathrm{~mm}$ dorsoventral with respect to dura). Probes were secured onto the skull using stainless-steel screws and dental acrylic. Twenty-four hours after surgery, in vivo microdialysis was performed on conscious and freemoving mice. Probes were perfused continuously with artificial CSF (147 mM NaCl, $4 \mathrm{mM} \mathrm{KCl}$, and $\left.2.3 \mathrm{mM} \mathrm{CaCl}_{2}\right)$ at a rate of $2 \mu \mathrm{l} / \mathrm{min}$. D-Aalnine $(100 \mathrm{mg} / \mathrm{kg})$ with or without CBIO (30 mg/kg) was orally administered into mice. The dialysate was collected in 30-min fractions, and then stored at $-80^{\circ} \mathrm{C}$ before use.

Measurement of total, D- and L-alanine levels was carried out using a column-switching high performance liquid chromatography (HPLC) system (Shimadzu Corporation, Kyoto, Japan). To the $20 \mu$ of dialysis sample, $20 \mu \mathrm{L}$ of 0.1 $\mathrm{M}$ borate buffer ( $\mathrm{pH} \mathrm{8.0)}$ and $60 \mu \mathrm{L}$ of $50 \mathrm{mM}$ 4-fluoro-7nitro-2,1,3-benzoxadiazole (NBD-F; Tokyo Kasei Kogyo Co., Ltd., Tokyo, Japan) in $\mathrm{CH}_{3} \mathrm{CN}$ (HPLC grade) were added. The reaction mixture was then heated at $60^{\circ} \mathrm{C}$ for 1 min, and immediately supplemented with $100 \mu \mathrm{L}$ of $\mathrm{H}_{2} \mathrm{O}$ / $\mathrm{CH}_{3} \mathrm{CN}(90 / 10)$ containing $0.1 \%$ trifluoroacetic acid to stop the reaction.

A $20 \mu \mathrm{L}$ aliquot of the resultant solution was injected into the HPLC system. A reversed-phase ODS column [TSKgel ODS-80Ts (Tosoh Corporation, Tokyo, Japan) as Column 1] was used for the separation and quantification of total (D- and L-) alanine, and the gradient elution of the mobile phase was maintained at a constant flow rate of 0.8 $\mathrm{mL} / \mathrm{min}$. Mobile phase 1 a consisted of $\mathrm{H}_{2} \mathrm{O} / \mathrm{CH}_{3} \mathrm{CN}(90 / 10)$ containing $0.1 \%$ TFA, and phases $1 \mathrm{~b}$ and $1 \mathrm{c}$, of $\mathrm{H}_{2} \mathrm{O} / \mathrm{CH}_{3} \mathrm{CN}$ (10/90) containing $0.1 \%$ TFA and $\mathrm{CH}_{3} \mathrm{CN}$, respectively. The time program for gradient elution was as follows: 0 - $40 \mathrm{~min}$ $1 \mathrm{a}: 1 \mathrm{~b}: 1 \mathrm{c}=80: 20: 0,40-55 \min 1 \mathrm{a}: 1 \mathrm{~b}: 1 \mathrm{c}=0: 100:$ 0 , and $55-57 \mathrm{~min}, 1 \mathrm{a}: 1 \mathrm{~b}: 1 \mathrm{c}=0: 0: 100$. The chiral column (Column 2) used for the separation and quantification of D- and L-alanine with NBD-F comprised two Sumichiral OA-2500 columns (S) (Sumika Chemical Analysis Service Ltd., Osaka, Japan), which were connected in tandem. The mobile phase was $15 \mathrm{mM}$ citric acid in $\mathrm{MeOH}$. The flow rate was isocratically pumped at $0.8 \mathrm{~mL} / \mathrm{min}$. The column temperature of all columns was maintained at $35^{\circ} \mathrm{C}$. Fluorescence detection was performed at $530 \mathrm{~nm}$ with an excitation wavelength at $470 \mathrm{~nm}$.

\section{Statistical Analysis}

The data are presented as the mean \pm standard error of the mean (S.E.M.). PPI was calculated as the percent inhibi- 
tion of the startle amplitude evoked by the pulse alone: \% PPI $=100 \times($ magnitude on pulse alone trial-magnitude on prepulse + pulse trial/magnitude on pulse alone trial). The PPI data were analyzed by multivariate analysis of variance (MANOVA). When appropriate, group means at individual $\mathrm{dB}$ levels were compared by one-way ANOVA, followed by Bonferroni/Dunn test. The results of the in vivo microdialysis were analyzed by two-way analysis of variance (ANOVA) for repeated measures, with treatment as the between-subjects factor, and time as the within-subjects factor. When appropriate, group means at individual time points were compared by unpaired Student t-test. Significance for the results was set at $\mathrm{p}<0.05$.

\section{RESULTS}

Effects of D-Alanine with or without CBIO on PPI Deficits after a Single Administration of Dizocilpine

Fig. (2) shows the effects of D-alanine (100, 300 or 1000 $\mathrm{mg} / \mathrm{kg})$ with or without CBIO $(30 \mathrm{mg} / \mathrm{kg})$ on dizocilpine $(0.1$ $\mathrm{mg} / \mathrm{kg}$ )-induced PPI deficits in mice. The MANOVA analysis of all PPI data revealed that there was a significant effect [Wilks lambda $=0.384, \mathrm{P}<0.001]$. Subsequent ANOVA analysis revealed the significant differences at all $\mathrm{dB}$ groups $(69,73,77$, and $81 \mathrm{~dB})$. A posteriori analysis indicated a significant $(\mathrm{P}<0.001)$ difference between vehicle + vehicle group and vehicle + dizocilpine $(0.1 \mathrm{mg} / \mathrm{kg})$ group (Fig. 2). Higher doses (300 or $1000 \mathrm{mg} / \mathrm{kg}$ ) of D-alanine alone significantly attenuated PPI deficits induced by dizocilpine $(0.1$ $\mathrm{mg} / \mathrm{kg}$ ) (Fig. 2). However, the low dose (100 mg/kg) of D- alanine alone did not alter PPI deficits induced by dizocilpine. Interestingly, co-administration of CBIO $(30 \mathrm{mg} / \mathrm{kg})$ with D-alanine $(100 \mathrm{mg} / \mathrm{kg})$ significantly attenuated dizocilpine-induced PPI deficits at $73 \mathrm{~dB}(\mathrm{P}=0.006)$, and $77 \mathrm{~dB}$ $(\mathrm{P}=0.009)$, and $81 \mathrm{~dB}(\mathrm{P}<0.001)$ (Fig. 2). In contrast, $\mathrm{CBIO}$ $(30 \mathrm{mg} / \mathrm{kg})$ alone did not alter PPI in control mice (Fig. 2). Treatment with CBIO (30 mg/kg) alone was no effect on dizocilpine-induced PPI deficits in mice, as reported previously [35].

\section{Effects of CBIO on Extracellular Levels of D-Alanine in the Frontal Cortex after a Single Oral Administration of D-Alanine}

In order to explore the effects of CBIO on the extracellular levels of $\mathrm{D}$-alanine in the brain, we used an in vivo microdialysis technique to examine in extracellular D-alanine levels in the frontal cortex of conscious mice. Two-way repeated ANOVA analysis revealed significant differences among the two groups $[\mathrm{F}(1,8)=14.39, \mathrm{p}=0.005]$. Coadministration of D-alanine $(100 \mathrm{mg} / \mathrm{kg})$ and CBIO (30 $\mathrm{mg} / \mathrm{kg}$ ) significantly increased the extracellular D-alanine levels in the mouse frontal cortex as compared with Dalanine $(100 \mathrm{mg} / \mathrm{kg})$ alone treated group (Fig. 3).

\section{DISCUSSION}

The present findings suggest that administration of DAAO inhibitor CBIO could potentiate the bioavailability of D-alanine in mice after oral administration. In this study, we found that co-administration of CBIO $(30 \mathrm{mg} / \mathrm{kg})$ potentiated

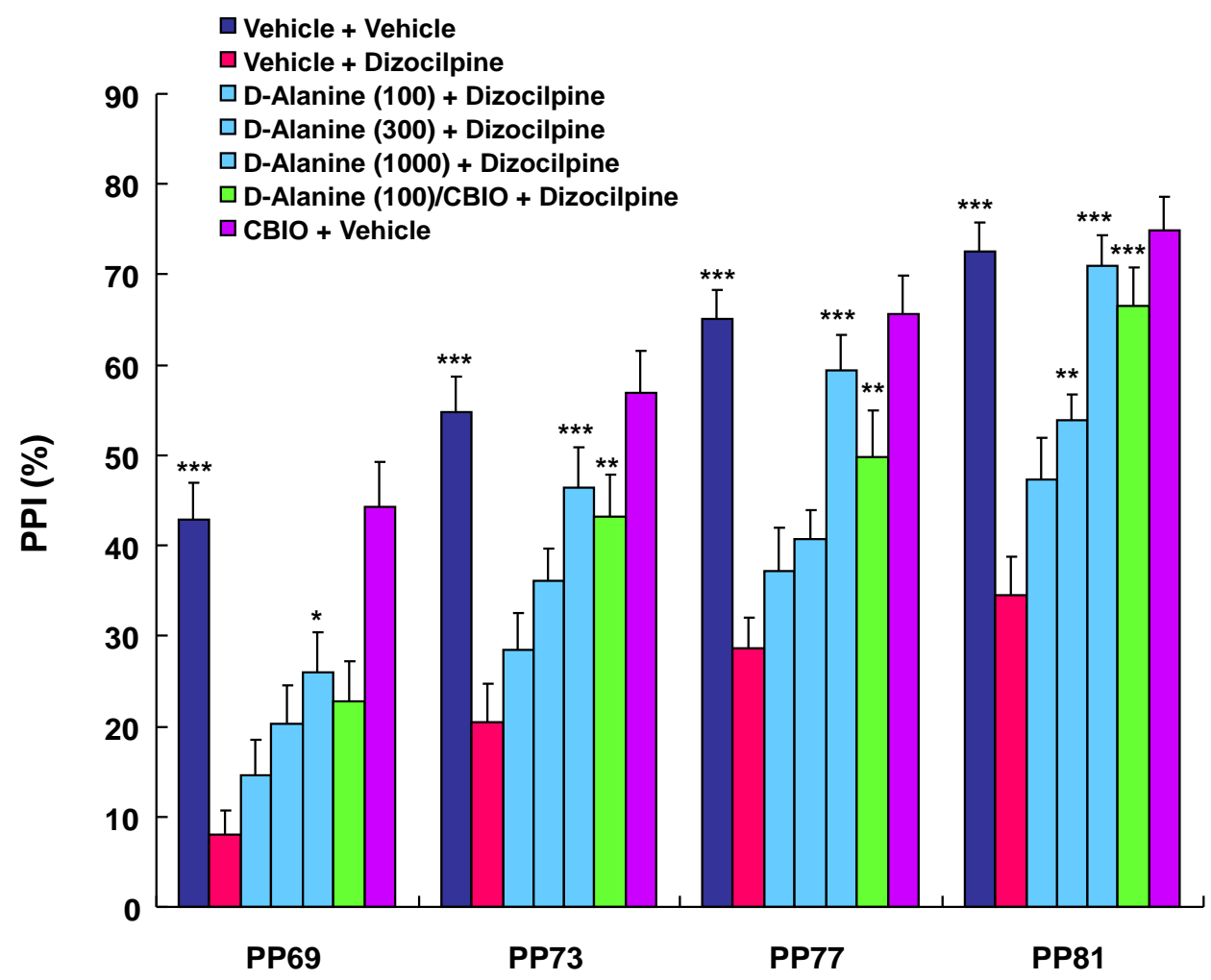

Fig. (2). The effect of D-alanine with or without CBIO on dizocilpine-induced PPI deficits in mice.

Sixty minutes after oral administration of vehicle (10 ml/kg), D-alanine (100, 300 or $1000 \mathrm{mg} / \mathrm{kg}$.), D-alanine (100 mg/kg) plus CBIO (30 $\mathrm{mg} / \mathrm{kg})$ or CBIO $(30 \mathrm{mg} / \mathrm{kg})$ alone, dizocilpine $(0.1 \mathrm{mg} / \mathrm{kg})$ or vehicle $(10 \mathrm{ml} / \mathrm{kg})$ was administered s.c. to the mice. Each value is the mean \pm S.E.M. ( $\mathrm{n}=15$ or 16 per group). $* \mathrm{P}<0.05, * * \mathrm{P}<0.01, * * * \mathrm{P}<0.001$ as compared with vehicle + dizocilpine treated group. 


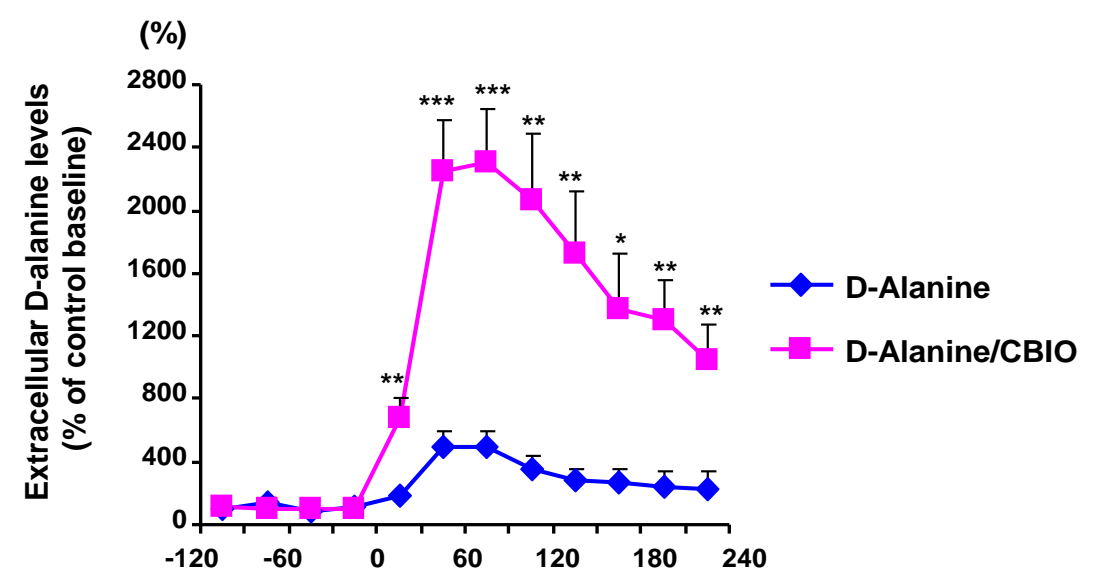

Time after oral administration (min)

Fig. (3). The effects of CBIO on extracellular D-alanine levels in the frontal cortex after oral administration of D-alanine.

Extracellular levels of D-alanine in the frontal cortex after oral administration of D-alanine $(100 \mathrm{mg} / \mathrm{kg})$ with or without CBIO (30 mg/kg) were measured by in vivo microdialysis in conscious and free-moving mice. $* \mathrm{P}<0.05$, $* * \mathrm{P}<0.01$, $* * * \mathrm{P}<0.001$ compared with the $\mathrm{D}$-alanine $(100 \mathrm{mg} / \mathrm{kg})$-treated group. Each value is the mean \pm S.E.M. ( $\mathrm{n}=6$ per group).

the efficacy of D-alanine $(100 \mathrm{mg} / \mathrm{kg})$ on dizocilpineinduced PPI deficits although D-alanine $(100 \mathrm{mg} / \mathrm{kg})$ alone was no effective in this model.

The in vivo microdialysis study in conscious and freemoving mice revealed that the extracellular levels of Dalanine in the frontal cortex after a single oral administration of D-alanine with CBIO were significantly higher than those of D-alanine alone group, indicating the increased oral bioavailability by the DAAO inhibitor CBIO. Thus, it is likely that enhancement of D-alanine by $\mathrm{CBIO}$ on dizocilpine-induced PPI deficits may be due to increased D-alanine levels in the brain. Furthermore, we reported that treatment with CBIO $(30 \mathrm{mg} / \mathrm{kg})$ alone was no effect on the extracellular D-serine levels in the rat brain because the permeability of CBIO into brain is not good [34]. Therefore, a combination therapy of D-alanine and a DAAO inhibitor (e.g., CBIO) could reduce the dose of $\mathrm{D}$-alanine in human since the dose (100 mg/kg for human) of D-alanine for treatment of schizophrenic patients is high [27].

Dr. Adage's group reported a slight increase in D-serine levels in rat brain following intravenous administration of a pyrazole-3-carboxylate based DAAO inhibitor (AS057278) alone [39], indicating that this effect may be due to its ability to penetrate the blood-brain barrier. Furthermore, Smith et al. [40] have developed the novel DAAO inhibitor $4 H-$ thieno[3,2-b]pyrrole-5-carboxylic acid $\left(\mathrm{IC}_{50}=145 \mathrm{nM}\right.$ for human, $\mathrm{IC}_{50}=114 \mathrm{nM}$ for rat). This compound failed to significantly influence amphetamine-induced psychomotor activity, nucleus accumbens dopamine release, or (+)-MK-801 (dizocilpine)-induced deficit in novel object recognition in rats, suggesting that acute inhibition of DAAO by this compound appears not to be sufficient to increase D-serine to concentrations required to produce antipsychotic and cognitive enhancing effects similar to those observed after administration of high doses of D-serine [40]. In contrast, there is no correlation between the distribution of DAAO and NMDA receptors in the brain [41, 42]. Therefore, even a brain-penetrable DAAO inhibitor may not be able to significantly enhance NMDA receptor-mediated neurotransmission by itself $[34,35]$.

\section{CONCLUSION}

In this study, we found that administration of DAAO inhibitor CBIO could enhance the oral bioavailability of Dalanine in mice, and that co-administration of D-alanine with CBIO significantly increased the extracellular D-alanine levels in the mouse frontal cortex as compared with Dalanine alone group. In conclusion, co-administration of Dalanine and a DAAO inhibitor would be a new approach for the treatment of schizophrenia.

\section{ACKNOWLEDGEMENTS}

This study was supported in part by grants from the Japan Society for the Promotion of Science (to K.H.). The authors have no financial interests or conflicts of interest to declare.

$\begin{array}{ll}\text { ABBREVIATIONS } \\ \text { ANOVA } & =\text { Analysis of variance } \\ \text { CBIO } & =\text {-Chloro-benzo }[d] \text { isoxazol-3-ol } \\ \text { CMC } & =\text { Carbomethoxycellulose } \\ \text { CSF } & =\text { Derebrospinal fluid } \\ \text { DAAO } & =\text { High performance liquid chromatography } \\ \text { HPLC } & =\text { Multivariate analysis of variance } \\ \text { MANOVA } & 4-F l u o r o-7-n i t r o-2,1,3-\text { benzoxadiazole } \\ \text { NBD-F } & =\text { N-Methyl-D-aspartate } \\ \text { NMDA } & =\text { Phencyclidine } \\ \text { PCP } & =\text { Prepulse inhibition } \\ \text { PPI } & =\text { Standard error of the mean } \\ \text { SEM } & =\end{array}$




\section{REFERENCES}

[1] Javitt, D.C.; Zukin, S.R. Recent advances in the phencyclidine model of schizophrenia. Am. J. Psychiatry, 1991, 148, 1301-1308.

[2] Olney, J.W.; Farber, N.B. Glutamate receptor dysfunction and schizophrenia. Arch. Gen. Psychiatry, 1995, 52, 998-1007.

[3] Coyle, J.T. The glutamatergic dysfunction hypothesis for schizophrenia. Harv. Rev. Psychiatry, 1996, 3, 241-253.

[4] Krystal, J.H.; D'Souza, D.C.; Petrakis, I.L.; Belger, A.; Berman, R.M.; Charney, D.S.; Abi-Saab, W.; Madonick, S. NMDA agonists and antagonists as probes of glutamatergic dysfunction and pharmacotherapies in neuropsychiatric disorders. Harv. Rev. Psychiatry, 1999, 7, 125-143.

[5] Goff, D.C.; Coyle, J.T. The emerging role of glutamate in the pathophysiology and treatment of schizophrenia. Am. J. Psychiatry, 2001, 158, 1367-1377.

[6] Tsai, G.; Coyle, J.T. Glutamatergic mechanisms in schizophrenia. Anпи. Rev. Pharmacol. Toxicol., 2002, 42, 165-179.

[7] Hashimoto, K.; Fukushima, T.; Shimizu, E.; Komatsu, N.; Watanabe, H.; Shinoda, N.; Nakazato, M.; Kumakiri, C.; Okada, S.; Hasegawa, H.; Imai, K.; Iyo, M. Decreased serum levels of D-serine in patients with schizophrenia: evidence in support of the Nmethyl-D-aspartate receptor hypofunction hypothesis of schizophrenia. Arch. Gen. Psychiatry, 2003, 60, 572-576.

[8] Hashimoto, K.; Okamura, N.; Shimizu, E.; Iyo, M. Glutamate hypothesis of schizophrenia and approach for possible therapeutic drugs. Curr. Med. Chem. - CNS Agents, 2004, 4, 147-154.

[9] Hashimoto, K.; Shimizu, E.; Iyo, M. Dysfunction of glia-neuron communication in pathophysiology of schizophrenia. Curr. Psychiatry Rev., 2005, 1, 151-163.

[10] Coyle, J.T.; Tsai, G. The NMDA receptor glycine modulatory site: a therapeutic target for improving cognition and reducing negative symptoms in schizophrenia. Psychopharmacology (Berl), 2004, 174, 32-38.

[11] Millan, M.J. N-Methyl-D-aspartate receptors as a target for improved antipsychotic agents: novel insights and clinical perspectives. Psychopharmacology (Berl), 2005, 179, 30-53.

[12] Hashimoto, K. The NMDA receptor hypofunction hypothesis for schizophrenia and glycine modulatory sites on the NMDA receptors as potential therapeutic drugs. Clin. Psychopharmacol. Neurosci., 2006, 4, 3-10.

[13] Hashimoto, K. Glycine transporter-1 inhibitors as novel therapeutic drugs for schizophrenia. CNS Agents Med. Chem., 2007, 7, 177182.

[14] Stahl, S.M. Novel therapeutics for schizophrenia: targeting glycine modulation of NMDA glutamate receptors. CNS Spectr., 2007, 12, 423-427.

[15] Javitt, D.C.; Spencer, K.M.; Thaker, G.K.; Winterer, G.; Hajós, M. Neurophysiological biomarkers for drug development in schizophrenia. Nat. Rev. Drug Discov., 2008, 7, 68-83.

[16] Hoeprich, P.D. Ananine: cycloserine antagonism. VI. Demonstration of D-alanine in the serum of guinea pig and mice. J. Biol. Chem., 1965, 240, 1654-1660.

[17] Konno, R.; Nagata, Y.; Niwa, A.; Yasumura, Y. Spontaneous excretion of D-alanine in urine in mutant mice lacking D-amino-acid oxidase. Biochem. J., 1989, 261, 285-287.

[18] Nagata, Y.; Masui, R.; Akino, T. The presence of free D-serine, Dalanine and D-proline in human plasma. Experientia, 1992, 48, 986-988.

[19] Nagata, Y.; Konno, R.; Niwa, A. Amino acid levels of D-alanineadministered mutant mice lacking D-amino acid oxidase. Metabolism, 1994, 43, 1153-1157.

[20] Brückner, H.; Hausch, M. Gas chromatographic characterization of free D-amino acids in the blood serum of patients with renal disorders and of healthy volunteers. J. Chromatogr., 1993, 614, 7-17.

[21] Hamase, K.; Homma, H.; Takigawa, Y.; Fukushima, T.; Santa, T.; Imai, K. Regional distribution and postnatal changes of D-amino acids in rat brain. Biochim. Biophys. Acta, 1997, 1334, 214-222.

[22] Morikawa, A.; Hamase, K.; Zaitsu, K. Determination of D-alanine in the rat central nervous system and periphery using columnswitching high-performance liquid chromatography. Anal. Biochem., 2003, 312, 66-72.

[23] Reynolds, I.J.; Murphy, S.N.; Miller, R.J. ${ }^{3}$ H-labeled MK-801 binding to the excitatory amino acid receptor complex from rat brain is enhanced by glycine. Proc. Natl. Acad. Sci. USA, 1987, 84, 7744-7748.
Kleckner, N.W.; Dingledine, R. Requirement for glycine in activation of NMDA-receptors expressed in Xenopus oocytes. Science, 1988, 241, 835-837.

[25] McBrain, C.J.; Kleckner, N.W.; Wyrick, S.; Dingledine, R. Structural requirements for activation of the glycine coagonist site of $\mathrm{N}$ methyl-D-aspartate receptors expressed in Xenopus oocytes. Mol. Pharmacol., 1989, 36, 556-565.

[26] Tanii,Y.; Nishikawa, T.; Hashimoto, A.; Takahashi, K. Stereoselective inhibition by D- and L-alanine of phencyclidine-induced locomotor stimulation in the rat. Brain Res., 1991, 563, 281-284.

[27] Tsai, G.E.; Yang, P.; Chang, Y.C.; Chong, M.Y. D-Alanine added to antipsychotics for the treatment of schizophrenia. Biol. Psychiatry, 2005, 59, 230-234.

[28] Verrall, L.; Walker, A.; Rawlings, N.; Benzel, I.; Kew, J.N.C.; Harrison, P.J.; Burnet, P.W. D-Amino acid oxidase and serine racemase in human brain: normal distribution and altered expression in schizophrenia. Eur. J. Neurosci., 2007, 26, 1657-1669.

[29] Madeira, C.; Freitas, M.E.; Vargas-Lopes, C.; Wolosker, H.; Panizzutti, R. Increased brain D-amino acid oxidase (DAAO) activity in schizophrenia. Schizophr. Res., 2008, 101, 76-83.

[30] Chumakov, I.; Blumenfeld, M.; Guerassimenko, O.; Cavarec, L.; Palicio, M.; Abderrahim, H.; Bougueleret, L.; Barry, C.; Tanaka, H.; La Rosa, P.; Puech, A.; Tahri, N.; Cohen-Akenine, A.; Delabrosse, S.; Lissarrague, S.; Picard, F.P.; Maurice, K.; Essioux, L.; Millasseau, P.; Grel, P.; Debailleul, V.; Simon, A.M.; Caterina, D.; Dufaure, I.; Malekzadeh, K.; Belova, M.; Luan, J.J.; Bouillot, M.; Sambucy, J.L.; Primas, G.; Saumier, M.; Boubkiri, N.; MartinSaumier, S.; Nasroune, M.; Peixoto, H.; Delaye, A.; Pinchot, V.; Bastucci, M.; Guillou, S.; Chevillon, M.; Sainz-Fuertes, R.; Meguenni, S.; Aurich-Costa, J.; Cherif, D.; Gimalac, A.; Van Duijn, C.; Gauvreau, D.; Ouellette, G.; Fortier, I.; Raelson, J.; Sherbatich, T.; Riazanskaia, N.; Rogaev, E.; Raeymaekers, P.; Aerssens, J.; Konings, F.; Luyten, W.; Macciardi, F.; Sham, P.C.; Straub, R.E.; Weinberger, D.R.; Cohen, N.; Cohen, D. Genetic and physiological data implicating the new human gene G72 and the gene for Damino acid oxidase in schizophrenia. Proc. Natl. Acad. Sci. USA, 2002, 99, 13675-13680.

[31] Detetra-Wadleigh, S.D.; McMahon, F.J. G72/G30 in schizophrenia and bipolar disorder: review and meta-analysis. Biol. Psychiatry, 2006, 60, 106-114

[32] Lyle, L.R.; Jutila, J.W. D-amino acid oxidase induction in the kidneys of germ-free mice. J. Bacteriol., 1968, 96, 606-608.

[33] Morikawa, A.; Hamase, K.; Inoue, T.; Konno, R.; Niwa, A.; Zaitsu, $\mathrm{K}$. Determination of free $\mathrm{D}$-aspartic acid, D-serine and D-alanine in the brain of mutant mice lacking D-amino acid oxidase activity. $J$. Chromatogr. B. Biomed. Sci., 2001, 757, 119-125.

[34] Ferraris, S.; Duvall, B.; Ko, Y.S.; Thomas, A.G.; Rojas, C.; Hashimoto, K.; Tsukamoto, T. Synthesis and biological evaluation of Damino acid oxidase inhibitors. J. Med. Chem., 2008, 51, 33573359.

[35] Hashimoto, K.; Fujita, Y.; Horio, M.; Kunitachi, S.; Iyo, M.; Ferraris, D.; Tsukamoto, T. Co-administration of a D-amino acid oxidase inhibitor potentiates the efficacy of D-serine in attenuating prepulse inhibition deficits after administration of dizocilpine. Biol. Psychiatry, 2009, in press.

[36] Swerdlow, N.R.; Braff, D.L.; Taaid, N.; Geyer, M.A. Assessing the validity of an animal model of deficient sensorimotor gating in schizophrenic patients. Arch. Gen. Psychiatry, 1994, 51, 139-154.

[37] Swerdlow, N.R.; Geyer, M.A. Using an animal model of deficient sensorimotor gating to study the pathophysiology and new treatments of schizophrenia. Schizophr. Bull., 1998, 24, 285-301.

[38] Zhang, L.; Shirayama, Y.; Iyo, M.; Hashimoto, K. Minocycline attenuates hyperlocomotion and prepulse inhibition deficits in mice after administration of the NMDA receptor antagonist dizocilpine. Neuropsychopharmacology, 2007, 32, 2004-2010.

[39] Adage, T.; Trillat, A.C.; Quattropani, A.; Perrin, D.; Cavarec, L.; Shaw, J.; Guerassimenko, O.; Giachetti, C.; Gréco, B.; Chumakov, I.; Halazy, S.; Roach, A.; Zaratin, P. In vitro and in vivo pharmacological profile of AS057278, a selective d-amino acid oxidase inhibitor with potential anti-psychotic properties. Eur. Neuropsychopharmacol., 2008, 18, 200-214.

[40] Smith, S.M.; Uslaner, J.M.; Yao, L.; Mullins, C.M.; Surles, N.O.; Huszar, S.L.; McNaughton, C.H.; Pascarella, D.M.; Kandebo, M.; Hinchliffe, R.M.; Sparey, T.; Brandon, N.J.; Jones, B.; Venkatraman, S.; Young, M.B.; Sachs, N.; Jacobson, M.A.; Hutson, P.H. The behavioral and neurochemical effects of a novel D-amino acid 
oxidase inhibitor compound 8 [4H-thieno [3,2-b]pyrrole-5carboxylic acid] and D-serine. J. Pharmacol. Exp. Ther., 2009, 328, 921-930.

[41] Schell, M.J.; Molliver, M.E.; Snyder, S.H. D-serine, an endogenous synaptic modulator: localization to astrocytes and glutamate- stimulated release. Proc. Natl. Acad. Sci. USA, 1995, 92, 39483952.

[42] Schell, M.J. The N-methyl D-aspartate receptor glycine site and Dserine metabolism: an evolutionary perspective. Philos. Trans. $R$. Soc. Lond. B Biol. Sci., 2004, 359, 943-964.

Received: March 5, 2009

Revised: March 13, 2009

Accepted: March 17, 2009

(C) Horio et al.; Licensee Bentham Open.

This is an open access article licensed under the terms of the Creative Commons Attribution Non-Commercial License (http://creativecommons.org/licenses/ by-nc/3.0/) which permits unrestricted, non-commercial use, distribution and reproduction in any medium, provided the work is properly cited. 